\title{
DETERMINING THE SUCCESS FACTORS OF SETTLEMENTS BASED ON THE EXPERIENCE OF VILLAGE- RESEARCH
}

\author{
Melinda Molnár Nagyné \\ associate professor \\ Faculty of Economics and Social Sciences, Szent István University \\ E-mail: nagyne.molnar.melinda@gtk.szie.hu
}

\begin{abstract}
The settlements are value-carriers. Of course not every valuable condition is a key of the success. The objective of this study is to survey the general success factors of settlements. The settlements as autonomies due to their far-reaching role-system possess means of different characteristics, which can strengthen or even weaken each other's effects. One part of the instruments used by the settlements are unique, whereas other instrument work alike everywhere. The success of settlement depends on whether they are aware of the factors that determine their success, and whether they find their own effective tools to reach their objectives. This study presents which factors could we identify that determine success, based on our village seminar researches that have been ongoing since 2007.
\end{abstract}

Keywords: sustainable development, success factors

JEL classification: $R 58$

LCC: GF 101-127

\section{Introduction}

It is generally believed that successful settlements can come into being where the citizens are also prosperous and successful; thus where the growth, the improvement of the quality of life appears also in the life of the community and of the individual. In this case the citizens are obviously content; they can create the properly multilateral and complex expression of interest (Bódi-Böhm, 2000). However, this scenario cannot be considered as a standard. Interpreting the success of settlements as the set of individual successes is a bit simplifying and idealistic. The individual successes do not always provide clear communal values. There is not in every case a long-term sustainable development behind such a success (Nagyné Molnár M 2013). The wording 'sustainable' was published first by Lester R. Brown in his book about sustainable society in 1982. In his work, he based sustainable society on the environmental degradation caused by the increase of population and use of natural resources as small as possible, both in the sense of quantity and quality. (Brown 1982, cited by: Szlávik 2007). The logic of sustainable development also states that the fundamental objective is to improve the life conditions and the quality of life. Compared to the strategies which were oriented to economic growth, the main difference is the judgment about economic development; in this case the emphatic objective is not the quantitative growth of the economy but the development of quality, and the economy serves as a means for this. (Csete 2006). If we examine based on this, what determines the quality of the space to be improved, we can see that it is influenced by several, interdependent factors. The locally available, inherently natural resources are called local energies, whereas the relative benefits are called conditional energies (Nagyné Molnár 2013). The synergistic success of these factors can ensure the most dynamic development arc of settlements (Kovács 2001). 
In this study I examine the social and economic success factors of the settlements based on concrete village research.

\section{Material and methods}

When establishing the model for the success factors of settlements, I built on the experience gained during the village seminar researches started in 2007. The village seminar workshop established partially by me has been researching continuously on 9 sample location. During the selection of sample locations, we were looking for locations that represent the characteristics of a process specific to a region. We used the village typing system of Beluszky-Sikos T. (2007) when we determined the characteristics of the villages selected. The 9 settlements examined: Siklód (Hargita county- Románia), Bag (Pest county), Komlóska (Borsod-Abaúj- Zemplén county), Baks (Csongrád county), Tiszaladány (Borsod-Abaúj-Zemplén county) Pázmánd (Fejér county), Átány (Heves county), Hollókő (Nógrád county), Egercsehi (Heves county). (Chart 1.)

In 2017, we began to return to our previous sites. This enabled the so called trend monitoring. The essence of trend monitoring is to follow the socially and economically relevant chronological changes of space. Going back to the sites from time to time allows us to see the changes in the research locations by recording the snapshots every now and then about the revealed characteristics in the analysis of economic, social, and regional principles at a specific timeline. It is thus important and desired that after summarizing the results of one specific deepboring the regional analysis on the specific location should not be interrupted. Long-term monitoring makes it possible to understand the deeper economic and social relations of the settlement/area.

The model to be described is built on the complex methodological research done year by year by the village seminar research group. During this process, the prevailing village seminar research team gathers the documents containing the description of the social, economic, natural resources of locations and the articles, studies and books written by the aspect of different science areas (history, folklore, economic geography). Our secondary researches lay the ground for the primary research. During this process, interviews are made related to the topic in question with participants who possess information that is relevant for the specific subject. Personal observation, as a method, serves as a means of gathering information based on experience which might bring us closer to the mechanism of a local phenomenon, institute, program, etc. During the observation without intervention we gather information by observing the processes and phenomena, and watching them from the outside. An example for such a research is mental mapping or traffic counting. During observation with intervention we are active participants of the process (for example, in the research of local economy development). The objective of the survey is to get information about $30 \%-40 \%$ of households in the whole settlement in proportion to the population. We aim thus to have proportional sampling during the survey: we always get less samples from shorter streets, and more samples from longer ones. (Chart 1) 
Chart 1: Locations of the village seminar researches

\begin{tabular}{|c|c|c|c|}
\hline $\begin{array}{l}\text { Name of } \\
\text { the village }\end{array}$ & County & $\begin{array}{l}\text { Type (Beluszky-Sikos } \\
\text { T. 2007) }\end{array}$ & Supplementary information \\
\hline Bag & $\begin{array}{l}\text { Pest } \\
\text { county }\end{array}$ & $\begin{array}{l}\text { Has a good labor market, } \\
\text { stagnant population, } \\
\text { high number of } \\
\text { commuters }\end{array}$ & $\begin{array}{l}\text { 1. The ratio of Romany has been } \\
\text { significantly increasing. } \\
\text { 2. The leading folk tradition village } \\
\text { along the Galga. }\end{array}$ \\
\hline Komlóska & \multirow[t]{2}{*}{$\begin{array}{l}\text { Borsod- } \\
\text { Abaúj- } \\
\text { Zemplén }\end{array}$} & \multirow[t]{2}{*}{$\begin{array}{l}\text { Population is rapidly } \\
\text { decreasing, small } \\
\text { villages with bad labor } \\
\text { market and a significant } \\
\text { number of agricultural } \\
\text { workers. }\end{array}$} & $\begin{array}{l}\text { 1. Rusin village } \\
\text { 2. Tourism is developing } \\
\text { 3. The establishment of non-agrarian } \\
\text { enterprises is significant (municipal } \\
\text { governmental incentives) }\end{array}$ \\
\hline Tiszaladány & & & $\begin{array}{l}\text { 1. It was transferred to BAZ county } \\
\text { with a public administration change. } \\
\text { 2. Tourism is non-existent, even though } \\
\text { Tokaj is in the vicinity } \\
\text { 3. The Romany minority is growing }\end{array}$ \\
\hline Baks & Csongrád & \multirow[t]{2}{*}{$\begin{array}{l}\text { Average labor market, } \\
\text { decreasing population, } \\
\text { settlements of } \\
\text { miscellaneous functions }\end{array}$} & $\begin{array}{l}\text { 1. Young village (became independent } \\
\text { in the mid-20th century), the twin of } \\
\text { Ópusztaszer } \\
\text { 2. No tourism } \\
\text { 3. The ratio of Romany is significant. }\end{array}$ \\
\hline Pázmánd & Fejér & & $\begin{array}{l}\text { 1. Lies close to the edge of the } \\
\text { agglomeration of Budapest } \\
\text { 2. Part of the tourist destination of } \\
\text { Velencei-tó }\end{array}$ \\
\hline Átány & \multirow[t]{2}{*}{ Heves } & \multirow{2}{*}{$\begin{array}{l}\text { Bad labor market, } \\
\text { middle-sized, stagnant } \\
\text { villages with lots of } \\
\text { commuters }\end{array}$} & $\begin{array}{l}\text { 1. A village with strong ties to peasant } \\
\text { culture. } \\
\text { 2. The Romany minority is significant }\end{array}$ \\
\hline Egercsehi & & & $\begin{array}{l}\text { 1. Former mining village } \\
\text { 2. The Romany minority is significant }\end{array}$ \\
\hline Hollókő & Nógrád & $\begin{array}{l}\text { Small village with } \\
\text { unfavorable } \\
\text { demographic processes, } \\
\text { but considerable } \\
\text { touristic roles }\end{array}$ & $\begin{array}{l}\text { 1. World Heritage } \\
\text { 2. Aging village }\end{array}$ \\
\hline Siklód & Hargita & - & $\begin{array}{l}\text { Cross-border, only Hungarian- } \\
\text { populated dead-end village with a } \\
\text { decreasing population, in the shadow } \\
\text { of the Sóvidék's "tourism industry". }\end{array}$ \\
\hline
\end{tabular}

Edited by: Melinda Molnár (2017) 94.p.

\section{Results}

\section{The interpretation of the success of settlements}

Success cannot be reduced to one sole factor. Although in the first place the public opinion interprets the success of the settlements from an economic viewpoint, in fact the success of a settlement is depending on several socio-economic factors. The soci-economic factors are in interaction with one another (Káposzta J. 2011). The field-research done in domestic 
settlements also prove this. The factors determining success are thus complex. Every factor that influences the local condition of existence and the quality of life has an effect on the development of the settlement, thus also on its success (Ludescher G. 2010). Behind the successful settlements stands a stable economy and community. According to Bartik (1995) and Čapkova (2005) the emphasis is on the positive quality of life besides having a sustainable development (Nagyné Molnár M. 2013).

\section{Factors of success}

On the basis of our field experience the following factors can be seen as the factors contributing to the success of the well-working settlements (Nagyné Molnár M. 2013):

- Useful local conditions

- Innovation seed (initiative force)

- Genuine management of the settlement

- Synchronization between the innovation seed and the management of the settlement

- Acceptability of the plans for future in the mind of the local people

- Active local community

- positive shadow-effect

- accessibility of the transportation

- positive internal image

- positive external image

The useful local conditions are such material things, regional circumstances, human resourceelements, which represent unique values in every settlement. To put it into other words, these sources are the settlement's material, mental and spiritual values. The wealth of the settlement can be counted among the material values, including the national wealth and the private means. Due to its nature the national wealth for the most part is nowadays charged with problemsolving and often with mortgage, thus it is difficult to mobilize it. Regarding the private means it can be said that they can be accessed usually only with the approval of the owner. Nevertheless, both kinds of these properties contain the possibility to create value. The typical method of the economic development of the wealth is converting it into money, the burdening, taking into the collective business (PPP constructions). But changing the development possibilities belongs also here, by this means overestimating wealth (e.g. regarding agricultural territories, or the alteration of the building possibilities). Similarly, the settlement's revenues can be regarded as material values, which secure the funds of everyday functioning, but along the proper scheme sources can be detached for other value-creating goals. The local communities' mental capacity and relations capital can be seen as mental values. Among the settlement's mental treasures are for instance the local architectural values, but the local historical values, which were accumulated by the local population can also be counted here. Thus to prosper locally explicit and also tacit knowledge is essential. The settlement's spiritual values are also counted as significant treasures. The genius loci manifest itself alike in the architectural environment, in the cleanness of the settlement but also in the speech of the people, their relation to each other and to the guests (Nagyné Molnár M. 2013).

However, the useful local conditions in themselves make no settlement successful. It is important to have an active innovator force, innovation seed; to have an innovator, active team which can create concepts worthy of development and ready-to-submit applications out of ideas. 
Certainly, the authentic local management is also crucial. It is an important experience we gained that the local management is not made authentic by getting power through the empowerment of the majority, but by serving not only the direct sympathizers but also the whole population of the settlement.

It is a lucky situation, when there is synchronization between the innovation seed and the genuine management of the settlement thus they cover each other. This means that shaping the directions of future-serving changes, innovations and the acceptability of the plans for future in the mind of the local people meet in the work of the local management of the settlement thus strengthening each other. It is less lucky and leads often to failure (for instance to by-elections) when the innovation seed and the local management do not support each other (Nagyné Molnár M. 2013).

Based on our field experience, it seems a common mistake that although the innovation seed, the authentic settlement management exists, and good local settlement management can be found, the planned investments, innovations, changes are not embedded properly into the local society by the settlement management. The "socialisation" of plans takes place but it is rather pro forma. As a matter of fact, it can ruin even good plans if it does not have the necessary social acceptance.

It is a very important, successful determining value of a settlement, to have a "seed" which unites and moves the community and if people representing various interests, values can connect to this. An active local community seed is thus needed. The community's internal structure, dynamics is a value, which can turn into a strategic resource when helping in mobilizing the local economical, social resources. In the active local communities, however, it is often a problem that only a narrow company is active in truth. This can be a problem due to the fact that in such a society the beneficial effect of the building of society by the active seed is not felt in the wider community. In itself the activity of a narrow community seed cannot result in a lasting success if behind it there is no adequate support from the part of the local community. The communal activity serves properly the success of the settlement only where the whole of the local community or at least the majority of it is supportive (Nagyné Molnár M. 2013).

The so-called "shadow-effect", when evaluating it as the factor determining success we start from the examination of a larger region determining the settlement's success. Our starting-point is that a settlement can be successful if that region, where it exists, is strengthening its efforts, secures support, and it has partners in geographical proximity to exploit the opportunities (Piskóti 2012). Nevertheless, the shadow-effect works not only in a positive sense but also in a negative one. We can experience this when the settlement possesses extraordinary potential but the medium, with which they are in geographical connection, holds it back, does not let it develop (Nagyné Molnár M. 2013).

Usually the accessibility of transportation is also an important factor of success. It is a fundamental advantage if the economical centres are easily and quickly accessible (with public transport and/or individual transport). The accessibility of the economical centres is a key issue not only for the role of employment in the centre but because the economical centre also secures the educational, cultural, health, etc. provision belonging to the higher quality of life (Nagyné Molnár M. 2013).

A settlement can be successful for the long term only if it has an own internal image, namely if the people living in the given region have a positive image from their own settlement. 
Nevertheless, a positive image can be built from a miscellaneous and controversial image. This needs adequate community building, well-defined goals; such ones as everyone can undertake, with which everyone can identify themselves. The head of the settlement has to be fully aware of the fact how the locals see their own settlement, what they regard as their strength, their weaknesses, dangers, opportunities (Nagyné Molnár M. 2013).

The external image is also significant from the viewpoint of the settlement's success. It is important that the settlement should be generally known, preferably with a positive content. It cannot be expected from every settlement to have a popularity identical with a touristically much frequented settlement. Nevertheless, it is important that every settlement should build its external image according to their conditions/opportunities, and to communicate it properly to the appropriate group. The external image of the settlements takes form thus partly with conscious communicational activity, partly with the not necessarily controlled common talk. When shaping the external image with conscious communication the aim is to create the settlement's own image, and to learn how to display itself, make it attractive and arouse interest in others (Nagyné Molnár M. 2013).

\section{Conclusions}

The main conclusion is that the success of the settlements cannot be reduced to one sole impact. Another misconception is that the success of the settlements is due to economic factors. The truth is that one part of the success factors is not at all an economic factor, but other impacts, which determine the quality of life. When establishing the structure of the success factors of settlements, I built on the experience gained during the village seminar research started in 2007. It is based on a complex socio-economic research of 9 specific villages.

There is no recipe for the success of settlements. On the particular spot, at the particular time every settlement has its own way to reach its success. The settlements and the surrounding social, economical sphere are constantly changing. Among the continuously changing conditions, those settlements can be truly successful which are able to adapt to their environment. On the basis of our field experience, the following factors can be seen as the factors contributing to the success of the well-working settlements: useful local conditions, innovation seed (initiative force), genuine management of the settlement, synchronization between the innovation seed and the management of the settlement, acceptability of the plans for future in the mind of the local people, active local community, positive shadow-effect, accessibility of the transportation, positive internal image, positive external image.

\section{References}

1. Bartik, T. J. (1995): Economic Development Strategies. Upjohn Institute Working Paper No. 95-33. Kalamazoo, MI: W.E. Upjohn Institute for Employment Research. http://research.upjohn.org/up_workingpapers/33

2. Beluszky P.- Sikos T.T. (2007): Változó falvaink (Magyarország falutípusai az ezredfordulón) Magyarország az ezredfordulón/ Stratégiai tanulményok a Magyar Tudományos Akadémián IV. A területfejlesztési program tudományos alapozása Budapest MTA Társadalomkutató Központ

3. Bódi, F.- Bőhm, A. (2000): A sikeres és sikertelen településekről (About Successful and Unsuccessful Settlements) In: Bódi F.- Böhm A.: Sikeres helyi társadalmak Magyarországon (Successful Local Society in Hungary) Agroinform Kiadóház Budapest 
4. Brown, L. R. (1982): Building a sustainable society. Society, 1982, Volume 19, Number 2, p. 75

5. Čapková, S. (2005): Local Government and Economic Development. - Čapková, S. (ed.) Local Government and Economic Development. Open Society Institute, Budapest, pp. 1-19.

6. Csete, M. (2006): A fenntarthatóság helyi megvalósítása. Gazdálkodás Agrárökonómiai Tudományos Folyóirat. (50) 16. sz. különkiadás

7. Káposzta, J (2011): Regionális Gazdaságtan Budapest Szaktudás Kiadóház ISBN 978615-5224-10-2

8. Kovács, Z. (2001): A települések fejlődése. In: Beluszky P- Kovács Z.- Olessák D. (szerk): A terület- és településfejlesztés kézikönyve. CEBA Kiadó. pp. 67-91

9. Ludescher, G. (2010): A vállalkozások és a közösségek szerepe a rurális térségek megújulásában ( Function of the enterprises and communities in connection with regeneration of the rural areas) IDResearch Kft./Publikon Kiadó, Pécs, 2010, 148 p.

10. Molnár, M. (2017): A SZIE faluszeminárium, mint speciális vidék-kutató mühely Pro Scientia Ruralis 2:1 pp- 92- 101

11. Nagyné Molnár, M. (2013): Terület- térségmarketing (Regional marketing) ISBN 978615-5183-79-9 Debreceni Egyetem Agrár- és Gazdálkodástudományok Centruma

12. Nagyné, Molnár Melinda (2013)? Factors of success in case of local society DETUROPE: CENTRAL EUROPEAN JOURNAL OF TOURISM AND REGIONAL DEVELOPMENT $5: 3$ pp. 63-70., 8 p.

13. Piskóti, I. (2012): Régió és településmarketing (Regional and Settlement marketing) Akadémiai Kiadó Budapest

14. Szlávik, J. (szerk.) (2007): Környezetgazdaságtan. BME GTK Közgazdaságtudományok Intézet. Budapest: Typotex Kiadó. 